\title{
PEMILIHAN MARKETPLACE DI MASA PANDEMI COVID-19 MENGGUNAKAN METODE MOORA
}

\author{
Sultan Chaeruddin ${ }^{1}$, Icih Sukarsih ${ }^{2}$, Respitawulan ${ }^{3}$ \\ 1,2,3 Program Studi Matematika, Fakultas Matematika dan Ilmu Pengetahuan Alam, Universitas Islam Bandung \\ Jl. Tamansari No.1, Bandung, Indonesia 40116 \\ Iahmad_10060217017@unisba.ac.id, ${ }^{2}$ sukarsih@unisba.ac.id, ${ }^{3}$ respitawulan@unisba.ac.id
}

\begin{abstract}
Abstrak - Pandemi COVID-19 telah melanda hampir di seluruh dunia. Pandemi ini juga merupakan sebuah masa di mana masyarakat dituntut melaksanakan kebiasaan baru atau dikenal dengan New Normal. Kebiasaan baru ini juga mempengaruhi cara masyarakat dalam berbelanja khususnya berbelanja di marketplace. Ketika pandemi, beberapa marketplace banyak melakukan kampanye untuk berbelanja online, akan tetapi tidak semua marketplace menjamin kebutuhan masyarakat pada masa pandemi COVID-19 oleh karena itu dengan memilih marketplace yang tepat maka masyarakat atau konsumen dapat memenuhi kebutuhan seperti produk kesehatan dan rumah tangga yang paling dicari di masa pandemi. Sistem Pendukung Keputusan (SPK) adalah alat bantu bagi seorang manajer atau pengambil keputusan untuk memecahkan masalah yang bersifat kompleks dan tidak terstruktur. Pada SPK, terdapat metode untuk memecahkan masalah pengambilan keputusan yaitu Multi Criteria Decision Making (MCDM), metode ini memiliki dua model yaitu Multi Attribute Decision Making (MADM) dan Multi Objective Decision Making (MODM). Metode Multi Objective Optimization on The Basis of Ratio Analysis (MOORA) adalah salah satu teknik dari model MADM. Pada penelitian ini terdapat empat marketplace yang menjadi alternatif yaitu Shopee, Tokopedia, Bukalapak, dan Lazada. Kemudian, terdapat empat lima kriteria ketika memilih suatu marketplace di masa pandemi COVID-19 yaitu Kelengkapan Produk (Rumah Tangga dan Kesehatan), Tampilan dan Kemudahan Untuk User (UI/UX), Respon Pelayanan, Jasa Pengiriman, dan Proses Transaksi. Metode MOORA digunakan untuk menentukan rekomendasi marketplace di masa pandemi COVID-19 dikarenakan adanya jenis kriteria yang saling bertentangan, di mana kriteria dalam penelitian ini terdapat Benefit dan Cost. Hasil dari perhitungan menggunakan metode MOORA diperoleh Shopee merupakan marketplace yang direkomendasikan di masa pandemi COVID-19.
\end{abstract}

Kata Kunci-Pandemi COVID-19, Marketplace, MOORA

Abstract-The COVID-19 pandemic has hit almost the entire world. This pandemic is also a period in which society is implementing a new habit or known as the New Normal. This new habit also affects the way people shop, especially shopping in the marketplace. During the pandemic, several marketplaces carried out campaigns for online shopping, but not all marketplaces guarantee the needs of the community during the COVID-19 pandemic, therefore by choosing the right marketplace, the public or consumers can meet needs such as health and household products that are most sought after in the world. pandemic period. Decision Support System (DSS) is a tool for a manager or decision maker to solve complex and unstructured problems. In DSS, there is a method for solving decision-making problems, namely Multi Criteria Decision Making (MCDM), this method has two models, namely Multi Attribute Decision Making (MADM) and Multi Objective Decision Making (MODM). The Multi Objective Optimization on The Basis of Ratio Analysis (MOORA) method is one of the techniques of the MADM model. In this study, there are four alternative marketplaces, namely Shopee, Tokopedia, Bukalapak, and Lazada. Then, there are four criteria when choosing a marketplace during the COVID-19 pandemic, namely Product Completeness (Household and Health), Display and User Convenience (UI/UX), Service Response, Delivery Service, and Transaction Process. The MOORA method is used to determine marketplace recommendations during the COVID-19 pandemic due to conflicting criteria, where the criteria in this study are Benefit and Cost. The results of calculations using the MOORA method are obtained by Shopee as a definite marketplace during the COVID-19 pandemic.

Keywords-COVID-19 Pandemic, Marketplace, MOORA 


\section{PENDAHULUAN}

Pandemi CORONA VIRUS DESEASE-19 atau COVID-19 di seluruh dunia telah menjadi bencana alam besar bagi negara-negara dunia. Sebagai salah satu Page|150 akibat dari pandemi COVID-19 masyarakat dunia terutama masyarakat Indonesia telah mengubah dan mengadopsi kebiasaan atau perilaku baru dalam kehidupan sehari-hari atau lebih dikenal dengan era New Normal atau Next Normal. McKinsey and Company menyatakan bahwa diantara perubahan perilaku yang terjadi adalah perubahan perilaku dalam mengonsumsi barang dan metode berbelanja.

Di antara jenis produk-produk yang paling dicari selama masa pandemi adalah produk kesehatan seperti surgical mask, handsanitizer, vitamin, face shield, dan lain sebagainya. Diikuti pula oleh produk rumah tangga contohnya disinfectant, sabun cuci tangan, tisu, dan sejenisnya.

Di masa pandemi COVID-19 masyarakat lebih cenderung menggunakan platform digital yaitu marketplace dalam berbelanja untuk mengurangi intensitas bepergian keluar rumah meskipun kepentingan mendesak [1]. The Nielsen Company juga merilis dalam risetnya berpendapat serupa bahwa cara hidup sehari-hari di New Normal yang sangat signifikan berubah adalah menggunakan marketplace untuk kepraktisan dan keamanan [2].

Berdasarkan survei yang dilakukan oleh Snapcart (2020) tentang dampak COVID-19 terhadap kebiasaan berbelanja orang Indonesia, sebagian besar $(78 \%)$ konsumen Indonesia telah melihat perubahan dalam kebiasaan belanja mereka karena wabah tersebut berdampak signifikan pada aktivitas sehari-hari mereka [3].

Pada riset tersebut Snapcart dipaparkan pula data marketplace yang paling sering digunakan ketika pandemi COVID-19 yaitu 66\% dari 1000 responden survei seluruh Indonesia memilih Shopee sebagai marketplace top of mind, kemudian ada Tokopedia dengan koresponden sebesar 16\%, Lazada dengan koresponden sebesar 12\%, 4\% Bukalapak [4].

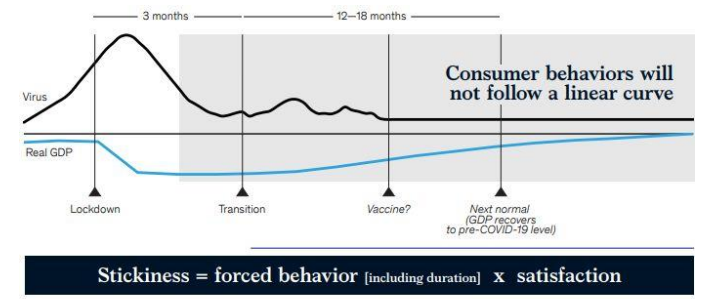

Our hypotheses on which changes could stick or dissipate - Nen trend Discontinuity Acceieration Unknow

Gbr 1. Perilaku Konsumen Pada Masa Pandemi [1].

Ketika memilih suatu marketplace di masa pandemi selain menilai dari kelengkapan produk, baik produk kesehatan dan produk rumah tangga, dapat juga dinilai marketplace tersebut dari tampilan situs atau aplikasi atau yang lebih dikenal dengan User Interface dan User Experience $(U I / U X)$, respon pelayanan marketplace seperti fitur chat dengan customer service, jasa pengiriman seperti memberikan gratis biaya kirim lalu ketepatan dalam estimasi waktu pengiriman, dan kemudahan dalam bertransaksi yang disediakan oleh marktetplace tersebut [5-13].

Sistem Pendukung Keputusan (SPK) adalah alat bantu yang diperuntukkan bagi seorang manajer atau pengambil keputusan untuk memecahkan berbagai masalah yang kompleks dan tidak terstruktur, sehingga dapat meningkatkan efektifitas dari keputusan yang diambil. Pada SPK terdapat metode untuk pengambilan keputusan yaitu Multi Criteria Decision Making (MCDM), metode ini memiliki dua model yaitu Multi Attribute Decision Making (MADM) dan Multi Objective Decision Making (MODM). Metode MultiObjective Optimization on the basis of Ratio Analysis (MOORA) termasuk teknik dalam model MADM [14]. Dalam metode MOORA terdapat kriteria benefit dan cost [15]. Keunggulan metode MOORA adalah sangat sederhana baik dari segi kalkulasi matematika maupun dari konsep yang mudah dipahami, fleksibel dan lebih stabil dibandingkan dengan metode lain. Metode MOORA diterapkan untuk memecahkan banyak permasalahan ekonomi, manajerial dan konstruksi pada sebuah perusahaan maupun proyek [16][17].

Berdasarkan penelitian-penelitian yang sudah ada sebelumnya penulis mengacu pada beberapa penelitian di antaranya adalah penelitian yang dilakukan oleh Yunianto dipilih Shopee, Tokopedia, dan Bukalapak sebagai alternatif berdasarkan riset yang dilakukan oleh Iprice, kriteria yang dipilih mengacu pada riset Alptekin yaitu dengan menilai kualitas website marketplace tersebut, Yunianto juga membagikan kuisioner penelitian untuk memperoleh nilai atribut untuk setiap alternatif dan berdasarkan hasil penelitian tersebut Shopee merupakan alternatif terbaik pada kuartal 2020 [18].

Penelitian serupa juga dilaksanakan oleh Ginting. Pada penelitian tersebut dipilih Shopee, Tokopedia, Bukalapak, Lazada, dan Blibli sebagai alternatif, dan hasil perhitungan menggunakan metode $S A W$ tersebut menyatakan bahwa Tokopedia adalah alternatif terbaik [19].

Pada penelitian berikutnya yaitu penelitian yang dilakukan oleh Chandra. Pada penelitian tersebut Chandra memilih kriteria pengambilan keputusan berdasarkan rating, review, dan komentar. Kemudian Chandra membuat suatu model dan sistem untuk marketplace agar pelanggan dapat menentukan toko online mana yang terbaik untuk membeli suatu produk berdasarkan rating yang sesuai dengan keinginan [20].

Pada penelitian terkait lainnya yaitu penelitian yang 
dilakukan oleh Acharjee, penelitian dilakukan yaitu pemilihan produk secara online dengan menggunakan fitur sistem rekomendasi dengan menganalisis pelanggan yang tepat melalui pengkategorian pengguna [21].

Page|151 $\begin{array}{r}\text { Pada penelitian selanjutnya yang dilakukan oleh } \\ \text { Wibowo. Pada penelitian tersebut Tokopedia, Shopee, }\end{array}$ dan Bukalapak menjadi alternatif yang diajukan berdasarkan riset Iprice, kriteria yang dipilih pun mengacu pada riset Alptekin yaitu dengan menilai kualitas website marketplace tersebut, Wibowo juga membagikan kuisioner penelitian untuk memperoleh nilai atribut untuk setiap alternatif. Berdasarkan ranking alternatif diperoleh Shopee yang dapat diusulkan menjadi alternatif terbaik [22].

Pada penelitian terkait terakhir yang dilakukan oleh Indra. Pada penelitian tersebut dipilih Lazada, Bukalapak, Tokopedia, OLX, Shopee, Blibli, Amazon, JDID, Mataharimall, dan Zalora sebagai alternatif yang diajukan, kriteria penelitian tersebut di antaranya pelayanan, produk, tampilan, pembayaran, dan pengiriman. Indra juga membagikan kuisioner penelitian untuk memperoleh nilai atribut untuk setiap alternatif. Hasil dari penelitian tersebut menyatakan bahwa Tokopedia merupakan e-commerce yang paling banyak diminati [23]

Berlandaskan data-data tersebut maka penulis bermaksud meneliti tentang perilaku konsumen di Indonesia menggunakan sistem pendukung keputusan untuk mengetahui kecenderungan konsumen dalam memilih marketplace di masa pandemi COVID-19 dan penelitian ini juga diharapkan dapat memberikan referensi bagi para calon konsumen atau pengguna baru aplikasi marketplace, serta penelitian ini dapat menjadi referensi riset untuk pengembangan bagi perusahaan penyedia jasa layanan marketplace di Indonesia di masa yang akan datang.

\section{METODOLOGI PENELITIAN}

Penelitian pemilihan marketplace di masa pandemi COVID-19 diawali dengan membagikan kuisioner penelitian yang telah diisi oleh 112 responden. Berdasarkan kuisioner penelitian tersebut diperoleh data yaitu rata-rata responden terdiri dari rentang usia 20-22 tahun, mayoritas berjenis kelamin perempuan, dan berprofesi sebagai mahasiswa. Data tersebut dihitung menggunakan skala likert dan hasilnya digunakan untuk memberikan nilai atribut pada setiap alternatif, hasil perhitungan menggunakan skala likert ini disajikan dalam Tabel 3 yang selanjutnya akan dibentuk matriks keputusan MOORA dari Tabel 3. Kemudian, dilakukan perhitungan menggunakan MOORA

Adapun algoritma perhitungan menggunakan metode MOORA sebagai berikut:

\section{Langkah 1:}

Menentukan tujuan untuk mengidentifikasi kriteria evaluasi yang dibicarakan dan meng-input-kan nilai kriteria pada setiap alternatif.

Langkah 2:

Membuat matriks keputusan MOORA.

$$
X=\left[\begin{array}{ccc}
x_{11} & \cdots & x_{1 n} \\
\vdots & \ddots & \vdots \\
x_{m 1} & \cdots & x_{m n}
\end{array}\right]
$$

Di (1) mana $X$ adalah matriks keputusan MOORA. Kemudian, $x_{i j}$ adalah alternatif ke- $i$ pada kriteria ke- $j$, dengan $i=1,2, \ldots, n$ adalah urutan alternatif, dan $j=$ $1,2, \ldots, m$ adalah urutan kriteria.

Langkah 3:

Membuat normalisasi matriks.

$x_{i j}^{*}$ adalah nilai normalisasi alternatif $i$ pada kriteria $j$, dengan

$$
x_{i j}^{*}=\frac{x_{i j}}{\sqrt{\sum_{j=1}^{m} x_{i j}^{2}}}
$$

$X^{*}$ adalah matriks ternormalisasi.

\section{Langkah 4:}

Menghitung Nilai Optimasi Multiobjektif MOORA.

Jika kriteria pada masing-masing alternatif diberikan nilai bobot kepentingan. Pemberian nilai bobot pada kriteria, dengan ketentuan nilai bobot jenis kriteria maximax lebih besar dari nilai bobot jenis kriteria minimax. Berikut rumus menghitung nilai Optimasi Multiobjektif MOORA:

$$
y_{i}=\sum_{j=1}^{g} w_{j} x_{i j}^{*}-\sum_{j=g+1}^{n} w_{j} x_{i j}^{*}
$$

Di mana $y_{i}$ adalah nilai yang telah dinormalisasi dari alternatif $i$ terhadap semua kriteria. Kemudian, $w_{j}$ adalah bobot setiap kriteria $j$.

Langkah 5:

Menentukan Ranking Berdasarkan Perhitungan MOORA.

Setelah diperoleh nilai $y_{i}$ dari masing-masing atribut, maka ditentukan ranking dari tiap alternatif berdasarkan nilai $y_{i}$ tertinggi hingga terendah.

\section{HASIL DAN PEMBAHASAN}

Pada penelitian ini, pemilihan marketplace di masa pandemi COVID-19 ditentukan menggunakan metode MOORA sehingga dapat menjadi rekomendasi bagi masyarakat ketika memilih marketplace dan menjadi rujukan evaluasi bagi alternatif-alternatif yang diteliti.

Berdasarkan tahapan penelitian yang telah dilaksanakan, diperoleh data berdasarkan penelitian terkait terdahulu dan hasil kuisioner penelitian yang telah diisi oleh 112 responden. 
Alternatif yang diperoleh berdasarkan riset yang dilakukan oleh Snapcart [4] diperlihatkan pada Tabel 1

TABEL I

ALTERNATIF MARKETPLACE

Page | 152

\begin{tabular}{|c|c|}
\hline Alternatif & Kode Alternatif \\
\hline Shopee & A1 \\
\hline Tokopedia & A2 \\
\hline Bukalapak & A3 \\
\hline Lazada & A4 \\
\hline
\end{tabular}

Berdasarkan penelitian yang dilakukan oleh Indra [23] maka diperoleh bobot tiap kriteria yang diperlihatkan pada Tabel 2

TABEL II

BOBOT KRITERIA MARKETPLACE

\begin{tabular}{|c|c|c|c|}
\hline Kriteria & $\begin{array}{c}\text { Kode } \\
\text { Kriteria }\end{array}$ & $\begin{array}{c}\text { Jenis } \\
\text { Kriteria }\end{array}$ & $\begin{array}{c}\text { Bobot } \\
\text { Kriteria } \\
(W j)\end{array}$ \\
\hline $\begin{array}{c}\text { Kelengkapan } \\
\text { Produk }\end{array}$ & $\mathrm{C} 1$ & Benefit & $25 \%$ \\
\hline$U I / U X$ & $\mathrm{C} 2$ & Benefit & $25 \%$ \\
\hline $\begin{array}{c}\text { Respon } \\
\text { Pelayanan }\end{array}$ & $\mathrm{C} 3$ & Benefit & $30 \%$ \\
\hline $\begin{array}{c}\text { Jasa } \\
\text { Pengiriman }\end{array}$ & $\mathrm{C} 4$ & Benefit & $10 \%$ \\
\hline $\begin{array}{c}\text { Proses } \\
\text { Transaksi }\end{array}$ & $\mathrm{C} 5$ & Cost & $10 \%$ \\
\hline
\end{tabular}

Berdasarkan Tabel 2 bobot kriteria tersebut bila dirubah dalam bentuk matriks baris maka diperoleh :

$$
W j=\left[\begin{array}{lllll}
0.25 & 0.25 & 0.3 & 0.1 & 0.1
\end{array}\right]
$$

Berdasarkan Tabel 1, Tabel 2, dan hasil kuisioner pada 112 responden menggunakan skala likert maka diperoleh nilai-nilai atribut untuk setiap alternatif, yang dapat dilihat pada Tabel 3

TABEL III

NILAI ATRIBUT UNTUK SETIAP ALTERNATIF

\begin{tabular}{|l|l|l|l|l|l|}
\hline Alternatif & C1 & C2 & C3 & C4 & C5 \\
\hline A1 & 485 & 443 & 452 & 483 & 498 \\
\hline A2 & 452 & 459 & 455 & 463 & 483 \\
\hline A3 & 447 & 405 & 412 & 403 & 426 \\
\hline A4 & 427 & 417 & 420 & 435 & 444 \\
\hline
\end{tabular}

Perhitungan menggunakan metode MOORA ditampilkan sebagai berikut:

Berdasarkan Tabel 3 dan persamaan (1) maka diperoleh matriks keputusan MOORA.

$$
X=\left[\begin{array}{lllll}
485 & 443 & 452 & 483 & 498 \\
452 & 459 & 455 & 463 & 483 \\
447 & 405 & 412 & 403 & 426 \\
427 & 417 & 420 & 435 & 444
\end{array}\right]
$$

Selanjutnya, berdasarkan persamaan (2) dan matriks $X$ maka yang selanjutnya dilakukan adalah menormalisasi matriks tersebut.
Normalisasi $x_{3,5}$

$$
x_{3,5}^{*}=\frac{426}{\sqrt{498^{2}+483^{2}+426^{2}+444^{2}}}=0.459
$$

Setelah menormalisasi seluruh unsur-unsur matriks $X$, maka diperoleh matriks ternormalisasi $X^{*}$

$$
X^{*}=\left[\begin{array}{lllll}
0.535 & 0.513 & 0.519 & 0.540 & 0.537 \\
0.498 & 0.531 & 0.522 & 0.517 & 0.520 \\
0.493 & 0.469 & 0.473 & 0.450 & 0.459 \\
0.471 & 0.483 & 0.482 & 0.486 & 0.478
\end{array}\right]
$$

Kemudian, dilakukan koefisien signifikasi untuk memudahkan perhitungan multi objektif MOORA

$$
\begin{aligned}
X^{*} W_{j}^{T} & =\left[\begin{array}{llllll}
0.535 & 0.513 & 0.519 & 0.540 & 0.537 \\
0.498 & 0.531 & 0.522 & 0.517 & 0.520 \\
0.493 & 0.469 & 0.473 & 0.450 & 0.459 \\
0.471 & 0.483 & 0.482 & 0.486 & 0.478
\end{array}\right]\left[\begin{array}{c}
0.25 \\
0.25 \\
0.3 \\
0.1 \\
0.1
\end{array}\right] \\
X^{*} W_{j} & =\left[\begin{array}{llllll}
0.133 & 0.128 & 0.155 & 0.054 & 0.053 \\
0.124 & 0.132 & 0.156 & 0.051 & 0.052 \\
0.123 & 0.117 & 0.141 & 0.045 & 0.045 \\
0.117 & 0.120 & 0.144 & 0.048 & 0.047
\end{array}\right]
\end{aligned}
$$

Untuk melakukan pemeringkatan alternatif dan memperoleh alternatif yang terbaik, maka tahap yang terakhir adalah menghitung nilai $y_{i}$ berdasarkan persamaan (3) pada Tabel 4 dan 5

TABEL IV PERHITUNGAN NILAI OPTIMASI MULTIOBJEKTIF

\begin{tabular}{|c|c|c|c|}
\hline Alternatif & $\begin{array}{c}\text { Benefit } \\
(\mathbf{C 1 + C 2 + C 3 + C 4 )}\end{array}$ & $\begin{array}{c}\text { Cost } \\
(\mathbf{C 5})\end{array}$ & $\begin{array}{c}y_{i} \\
\text { (Benefit- } \\
\text { Cost })\end{array}$ \\
\hline A1 & 0.47 & 0.053 & 0.417 \\
\hline A2 & 0.463 & 0.052 & 0.411 \\
\hline A3 & 0.426 & 0.045 & 0.381 \\
\hline A4 & 0.429 & 0.047 & 0.382 \\
\hline
\end{tabular}

TABEL V

PEMERINGKATAN ALTERNATIF

\begin{tabular}{|l|l|l|}
\hline Alternatif & \multicolumn{1}{|c|}{$y_{i}$} & Ranking \\
\hline A1 & 0.417 & 1 \\
\hline A2 & 0.411 & 2 \\
\hline A3 & 0.381 & 4 \\
\hline A4 & 0.382 & 3 \\
\hline
\end{tabular}

Berdasarkan Tabel 3.4.5 nilai $y_{i}$ tertinggi diperoleh oleh A1 yaitu Shopee dengan nilai $y_{i}$ sebesar 0.417, lalu disusul A2 yaitu Tokopedia dengan nilai $y_{i}$ sebesar 0.411, kemudian A4 yaitu Lazada dengan nilai $y_{i}$ sebesar 0.382, dan di posisi terakhir adalah A3 yaitu Bukalapak dengan nilai $y_{i}$ sebesar 0.381 . 


\section{IV.PENUTUP}

Berdasarkan perhitungan menggunakan metode MOORA, Shopee adalah marketplace yang direkomendasikan selama masa pandemi COVID-19 dari segi kelengkapan produk kesehatan dan rumah

Page | 153 tangga, interface dari situs dan aplikasi yang menarik dan mudah dioperasikan, respon pelayanan yang baik, jasa pengiriman yang hemat dan sesuai estimasi, dan proses transaksi yang variatif dan mudah, Shopee memperoleh nilai $y_{i}$ tertinggi yaitu sebesar 0.417, disusul oleh Tokopedia sebesar 0.411, kemudian Lazada sebesar 0.382, dan terakhir Bukalapak sebesar 0.3 .

Penelitian yang dilakukan penulis dapat menjadi evaluasi untuk masa yang akan datang bahwa seyogyanya para perusahaan marketplace senantiasa meningkatkan kualitas baik dari segi produk, kemudahan user dalam menavigasi, pelayanan yang responsif, dan kemudahan dalam bertransaksi melalui marketplace untuk meraih sebesar-besarnya konsumen di pasar agar diperoleh keuntungan yang lebih besar lagi di masa depan.

Saran untuk penelitian berikutnya adalah metode MOORA dapat dikombinasikan dengan metode-metode MADM lainnya dan logika fuzzy. Kemudian, pemilihan jasa pengiriman dan metode transaksi pada suatu marketplace dapat dijadikan objek penelitian berikutnya.

\section{UCAPAN TERIMA KASIH}

Terima kasih disampaikan kepada Program Studi Matematika, Fakultas Matematika dan Ilmu Pengetahuan Alam, Universitas Islam Bandung, dan semua pihak yang telah membantu atas terselesaikan nya penelitian ini.

\section{REFERENSI}

11] McKinsey and Company, "How COVID-19 is Changing Consumer Behavior Now and Forever," McKinsey and Company, Jakarta, 2020.

[2] The Nielsen Company, "Race Against The Virus, Indonesian Consumers Response Towards COVID-19," The Nielsen Company, Jakarta, 2020.

[3] Snapcart, "A PSBB Post Mortem \& Shifts In Consumer Trends," Snapcart, Jakarta, 2020.

[4] A. Husaini, "Riset Snapcart: Shopee Paling Diminati dan Jadi Pilihan Konsumen Belanja,” Kontan, 4 Juli 2020. [Online]. Available: https://industri.kontan.co.id/news/riset-snapcartshopee-paling-diminati-dan-jadi-pilihan-konsumen-berlanja. [Diakses 10 Agustus 2020].

[5] M. Mauris Unsuma, S. Gumilang Surya Fajar dan F. Anshary Al Mufied, "Prototype UI/UX Aplikas E-Marketplace "GEBBUK" Berdasarkan 8 Golden Rules of User Interface Design," e-Proceeding of Engineering, vol. 5, no. 2, pp. 3164 3169, 2018.

[6] A. Prakasa Goldina Iqbal dan F. Ardiansyah, "Perancangan User Experience Aplikasi Marketplace Paket Wisata Indonesia Untuk Wisatawan Lokal," Jurnal Ilmu Komputer dan AgriInformatika, vol. 5, no. 1, pp. 51-60, 2018.

[7] Y. Meidita, Suprapto dan R. Rokhmawati Indah, "Pengaruh Kualitas Layanan Terhadap Kepuasan, Kepercayaan dan Loyalitas Pelanggan Pada E-Commerce (Studi Kasus :
Shopee)," Jurnal Pengembangan Teknologi Informasi dan Ilmu Komputer, vol. 2, no. 11, pp. 5682-5690, 2018.

[8] Yudiyanto dan B. Berlinton, "Implementasi Aplikasi Jasa Pengiriman Barang Berbasis Android Pada CV Express Tri'yo Mujur," Jurnal Informatika dan Bisnis, vol. 4, no. 2, pp. 24-37, 2015.

[9] D. Achjari, "Potensi Manfaat dan Problem di E-Commerce," Jurnal Ekonomi dan Bisnis Indonesia, vol. 15, no. 3, pp. 388395, 2000.

[10] N. Putri Rosnadia Afifah dan S. Iriani Setyo, "Faktor-Faktor yang Memengaruhi Keputusan Pembelian di Shopee," Jurnal Komunikasi, Media, dan Informatika, vol. 8, no. 2, pp. 69-77, 2019.

[11] F. Alwafi dan R. Magnadi Hari, "Pengaruh Persepsi Keamanan, Kemudahan Bertransaksi, Kepercayaan Terhadap Toko dan Pengalaman Berbelanja Terhadap Minat Beli Secara Online Pada Situs Jual Beli Tokopedia," Diponogoro Journal of Management, vol. 5, no. 2, pp. 1-15, 2016

[12] I. Artaya Putu dan T. Purworusmiardi, "Efeketifitas Marketplace Dalam Meningkatkan Konsentrasi Pemasaran dan Penjualan Produk Bagi UMKM di Jawa Timur," Fakultas Ekonomi dan Bisnis Universitas Narotama, pp. 1-10, 2019.

[13] K. Ilmiyah dan I. Krishernawan, "Pengaruh Ulasan Produk, Kemudahan, Kepercayaan, dan Harga Terhadap Keputusan Pembelian Pada Marketplace Shopee di Mojokerto," Jurnal Manajemen, vol. 6, no. 1, pp. 31-42, 2020.

[14] L. FA, "Multi-Criteria Decision Analysis via Ratio and Application of The MOORA Method," in Proceedings of The 25th Difference Judgement, London, 1999

[15] M. U K and S. B, "Selection of Best Intelligent Manufacturing System Under Fuzzy MOORA Conflicting MCDM Environment," International Journal of Emerging Technology and Advanced Engineering, vol. 2, no. 9, pp. 301-310, 2012

[16] B. William K, Z. Edmundas Kazimieras and P. F, "Multi Objective Decision Making for Road Design," TRANSPORT, vol. 3, no. 23, pp. 183-193, 2008.

[17] B. William K and Z. Edmundas Kazimieras, "Multi-Objective Contractor's Ranking by Applying The MOORA Method," Journal of Business Economics and Management, vol. 9, no. 4, pp. 245-255, 2010.

[18] E. Yunianto dan J. D. Siregar, "Pemilihan EMarketplace Di Indonesia Pada Kuartal Pertama Tahun 2020 Menggunakan Metode Fuzzy MOORA," Journal IC Tech, vol. 15, no. 1, pp. 29-33, 2020.

[19] J. Ginting Br Veronika, "Penerapan Sistem Pendukung Keputusan Dalam Menentukan E-Commerce Terbaik Menggunakan Metode SAW," Jurnal Media Informatika Budidarma, vol. 4, no. 1, pp. 225-228, 2020.

[20] Y. Chandra Utama, S. Karya and M. Hendrawaty, "Decision Support Systems for Customer to Buy Products with an Integration of Reviews and Comments From Marketplace Ecommerce Sites in Indonesa: A proposed Modal," International Journal on Advanced Science Engineering Information Technology, vol. 9, no. 4, pp. 1171-1176, 2019.

[21] S. Acharjee, S. Abujar, S. Acharjee and S. Islam, "Decision Support Systems For Online Product Recommendation Service Based on Consumer Behavior," International Journal of Computer Applications, vol. 174, no. 8, pp. 34-37, 2017.

[22] A. Wibowo Putra dan A. Yunianto, "Pemilihan EMarketplace Dengan Metode Fuzzy AHP-VIKOR,” Jurnal IC Tech, vol. 14, no. 2, pp. 31-38, 2019.

[23] E. Indra dan J. Billy, "Sistem Pendukung Keputusan Untuk Menentukan E-Commerce Yang Banyak Diminati Dengan Metode SAW," dalam Prosiding Seminar Nasional Inovasi Teknologi dan Ilmu Komputer, Medan, 2018.

[24] Elite Marketer, "E-Commerce : 32 Marketplaces dan Platform Online Terbaik di Dunia,” Elite Marketer, [Online]. Available: https://elitemarketer.id/toko-online/bisnis-online-ecommerce-32-marketplaces-dan-platform-online/. [Diakses 25 Oktober 2020].

[25] CNN Indonesia, "Daftar Toko Online yang Paling Menguasai Pasar RI Selama 2019,” CNN Indonesia, 25 Januari 2020. [Online].

Available: https://www.cnnindonesia.com/teknologi/20200124205259- 
206-468540/daftar-toko-online-yang-paling-menguasai-pasarri-selama-2019. [Diakses 25 Oktober 2020].

[26] CNN Indonesia, "Tren dan Peluang Industri E-Commerce di Indonesia 2020," CNN Indonesia, 6 Februari 2020. [Online]. Available:

https://www.cnnindonesia.com/teknologi/20200205204206-

Page | 154 206-472064/tren-dan-peluang-industri-e-commerce-diindonesia-2020. [Diakses 25 Oktober 2020].

[27] R. Larasati Ayu, "Ingin Berjualan, Lebih Pas di Media Sosial, Market Place atau Situs Sendiri?," Kompas, 14 November $2019 . \quad$ [Online]. Available: https://money.kompas.com/read/2019/11/14/070800026/ingin -berjualan-lebih-pas-di-media-sosial-market-place-atau-situssendiri-. [Diakses 25 Oktober 2020].

[28] E. Wibowo Agung, "Pemanfaatan Teknologi E-Commerce Dalam Proses Bisnis,” Jurnal Equilibiria, vol. 1, no. 1, pp. 96 $108,2014$.

[29] A. Syuhada Anshorimuslim and W. Gambetta, "Online Marketplace for Indonesian Micro Small and Medium Enterprises Based on Social Media," in The 4th International Conference on Electrical Engineering and Informatics (ICEEI 2013), Selangor, 2013.

[30] R. Hondro Kristianto, Mengerjakan Soal Kasus Sistem Pendukung Keputusan, Medan: Universitas Budi Darma, 2017. 